\title{
CHARACTERIZATION OF AL-SI-NI TERNARY ALLOY SYNTHESIS FROM REDUCTION OF SODIUM-FLUOSILICATE AND NICKEL OXIDE
}

\author{
Mohammed. Farag ${ }^{1}$, Moatasem M. Kh ${ }^{1}$, A. A. Atlam ${ }^{2}$, and A. M. Omran ${ }^{1 *}$ \\ ${ }^{1}$ Mining and Metallurgical Engineering Department, Faculty of Engineering, Al-Azhar University, \\ Qena- Egypt \\ ${ }^{2}$ Mining and Petroleum Engineering, Faculty of Engineering, Al_Azhar University, Cairo- Egypt. \\ Corresponding author
}

\begin{abstract}
A new Al-Si-Ni high-temperature processed alloy has been obtained using sodium fluosilicate as a source of Si and nickel oxide as a source of Ni. Throughout the study, we tested the optimum parameters affecting the preparation of $\mathrm{Al}-\mathrm{Si}-\mathrm{Ni}$ ternary alloy; bath temperature, $\mathrm{Na}_{2} \mathrm{SiF}_{6} / \mathrm{Al}_{\text {total }}$ w.t ratio, $\mathrm{Ni}_{2} \mathrm{O}_{3} / \mathrm{Al}_{\text {total }}$ and reaction time. The optimum processing parameters are; temperature $950^{\circ} \mathrm{C}, \mathrm{Na}_{2} \mathrm{SiF}_{6} / \mathrm{Al}_{\text {total }}$ wt. ratio is $1, \mathrm{Ni}_{2} \mathrm{O}_{3} / \mathrm{Al}_{\text {total }}$ wt. ratio is 0.082 and reaction time is $25 \mathrm{~min}$. Some tests such as chemical analysis, X-ray diffraction and microstructure examination were carried out on the produced alloys. The obtained results indicate that the produced alloys containing up to $10.75 \% \mathrm{Si}$ and $2.86 \mathrm{Ni}$ in the form of $\mathrm{Al}_{3} \mathrm{Ni}$. The presence of eutectic $\mathrm{Si}$ and eutectic $\mathrm{Al}_{3} \mathrm{Ni}$ could form interconnected system and it can be used as high-performance alloys at elevated temperature.
\end{abstract}

Key words: High temperature alloys, Sodium fluosilicate, Al-Si-Ni ternary alloy, Nickel oxide.

\section{INTRODUCTION}

Al-Si alloys are widely accepted as casting alloys for industries due to their excellent casting characteristics, high castability, low specific gravity, good wear and corrosion resistance, and good weldability. Application of binary Al-Si alloys varies from domestic food components to automotive and aircraft parts, some of which include cylinder heads and intake manifolds to achieve greater weight reduction. [1]

Conventionally, Al-Si alloys were prepared by adding relatively pure silicon to molten aluminum at temperature about $900{ }^{\circ} \mathrm{C}$ in muffle furnaces [2]

Specific alloying elements like $\mathrm{Ni}, \mathrm{Cu}$ and $\mathrm{Mg}$ were tested to improve the high temperature strength of $\mathrm{Al}-\mathrm{Si}$ foundry alloys to certain limits by various strengthening mechanisms.[3] However, the positive effect of the four classical strengthening mechanisms, e.g. solid solution hardening, grain boundary hardening, work hardening, and precipitation hardening, is reduced at elevated temperatures.[4]

The effects of adding nickel on microstructure and mechanical properties of AluminumBased Alloys investigated by F. Hernández-Méndez, et al [5]. They found that the microstructure of the aluminum-nickel alloys present a thin and homogeneous distribution of an intermetallic compound in the aluminum's matrix, that identified as $\mathrm{Al}_{3} \mathrm{Ni}$, and the amount of intermetallic $\mathrm{Al}_{3} \mathrm{Ni}$ increases as the nickel content in the alloy rises.

Nickel Oxide is found in various types, the main type of Nickel is the green one called Ni II (NiO).Nickel oxide. $\mathrm{NiO}$ is an important transition metal oxide with cubic lattice structure. It has attracted increasing attention owing to potential use in a variety of applications such as: 
catalysis, battery cathodes, gas sensors, electrochromic films. The second one is black called $\mathrm{Ni}$ III $\left(\mathrm{Ni}_{2} \mathrm{O}_{3}\right)$ has a specific gravity about 4.84 , it decomposed into $\mathrm{NiO}$ and oxygen at $600^{\circ} \mathrm{C}$.[6,7] Ni containing aluminides are formed and increase the total coherence even after thermal solution processing. This factor enhances the amount of eutectic in the particular alloy. Furthermore, it is shown that there are upper limits for adding $\mathrm{Ni}$ in order to get a positive contribution in case of increasing elevated temperature strength, depending on the $\mathrm{Si}$ content of the alloy. For an optimized performance/cost relationship, the $\mathrm{Si} / \mathrm{Ni}$ ratio has to be taken into account $[8,3]$

The solubility of nickel in aluminum cannot exceed than $0.04 \mathrm{wt} \%$. If this amount exceeds, it would present an insoluble intermetallic, especially in combination with iron. Nickel content, up to $2 \mathrm{wt} \%$, increases the strength of high-purity aluminum but reduces its ductility. Binary Al-Ni alloys are no longer in use, but nickel is added to Al-Si alloys to improve both hardness and strength parameters at elevated temperatures as well as to reduce the coefficient of thermal expansion [9]

In a number of studies $[10,11]$ about Al-Si casted alloys, it is shown that nickel variations of up to $2-3 \%$ affect only the specific gravity, among the usual physical properties. Nickel is present largely as a relatively massive acicular dispersion of $\mathrm{Al}_{3} \mathrm{Ni}$ and the amount of this compound increases steadily with increasing the nickel content.

Asghar et al. [12] reported that the elevated temperature strength, up to $400^{\circ} \mathrm{C}$, of cast aluminum alloys is slightly improved by adding 0.6-1.96wt\% of Ni. It was shown that adding $1.2 \mathrm{wt} \%$ of $\mathrm{Ni}$ to Al-Si alloy resulted in the formation of $\sim 8 \mathrm{vol} . \%$ of $\mathrm{Fe}$ and $\mathrm{Ni}$ aluminides.

The structure of Al-Si eutectic melts with additions of Ni revealed changes corresponding to the formation of chemically ordered microgroups with AlNi and Al3Ni topology. The fraction of such structural units increases with increasing Ni content [13].

The transition elements can form trialuminides with the above characteristics that will contribute to the improvement of high temperature properties. The transition elements forming thermodynamically stable trialuminides intermetallics are e.g. Sc, Y, Ti, $\mathrm{Zr}$ [14].

The highly price of $\mathrm{Ni}$ is nearly three times higher that of the copper. Both the alloy producers and the customers of automotive industry are economically interested in finding another method to produce Al-Si-Ni alloys [3] .

The main objectives of the present study are to prepare high elevated temperature strength $\mathrm{Al}-\mathrm{Si}$-Ni ternary alloys using sodium fluosilicate as a source of $\mathrm{Si}$ and nickel oxide as a source of $\mathrm{Ni}$. The optimization of the parameters affecting the preparation of Al-Si-Ni ternary alloys is the second aim of this study.

\section{2- EXPERIMENTAL WORK}

The materials used to carry out the experiments of the present work are: Commercial aluminum with purity of $(99.7 \%)$, Al supplied by the aluminium company of Egypt (EGYPTALUM). The chemical analysis, as received material, was analyzed with inductively coupled plasma (ICP) model (OES), The used aluminum powder in this study has a purity $(98.47 \%)$ and the particle size was $(-125+63 \mu \mathrm{m})$ mesh. It is obtained as a product from AlGomhoria Company, Egypt for chemicals. The sodium fluosilicate $\left(\mathrm{Na}_{2} \mathrm{SiF}_{6}\right)$ powder used in this work has a purity of $99 \%$; it was supplied from Al-Gomhoria Company, Egypt for chemicals. The nickel oxide $\left(\mathrm{Ni}_{2} \mathrm{O}_{3}\right)$ used in this work in the form of gray powder with a purity of $99.5 \%$, and the particle size was $(1 \mu \mathrm{m})$ mesh it was supplied from Al-Gomhoria Company, Egypt for chemicals. Appropriate quantity of aluminum (150 g) was placed in a graphite crucible in the vertical tube furnace at a specified temperature $\left(800-1000^{\circ} \mathrm{C}\right)$, then a predetermined quantity of aluminum powder, $\mathrm{Na}_{2} \mathrm{SiF}_{6}$ and $\mathrm{Ni}_{2} \mathrm{O}_{3}$ were mixed at required ratios and compacted together, the target of addition of $\mathrm{Al}$ powder to increase the surface area between $\mathrm{Al}$ powder, nickel oxide and sodium fluosilicate, then added to the molten aluminum at designated ratios. The compacted mixture is stirred mechanically by Stirrer device (Janke \& Kunkle, RE 162/p, USA, maximum speed 600 RPM, mixing and overhead stirrer controller.) within the molten aluminum bath using a graphite rod. After a certain time ranged between 5-30 min., the crucible containing the molten alloy and slag were taken out of the furnace to separate the slag from the melt, and then the molten alloy was poured into a steel mold. Suitable solid specimens were prepared to carry out the chemical analysis, 
microstructure examinations (carried out by Scanning Electron Microscopy (SEM, FEI Inspect S50, Germany attached to energy dispersive X-ray spectrometer (EDS) for performing semi-qualitative elemental analysis for the specimens and polarized reflected light microscope (Model-OLYMPUS BX51, Japan) supplied with a digital camera (Leica DM500) and four objective lenses of different magnification including $4 \mathrm{x}, 10 \mathrm{x}, 50 \mathrm{x}$, and $100 \mathrm{x}$, and X-ray diffraction analysis (XRD) obtained from a Siemens D5000 diffractometer, Germany model using $\mathrm{Cu}$ radiation set at step size $0.02^{\circ}$ and step time 0.1 . The etchant solution used in the microstructure examination is $0.5 \% \mathrm{HF}$. it is prepared by diluting hydrofluoric acid (HF) 40 $\%$ with distilled water.

\section{3- RESULTS AND DISCUSSIONS}

\section{3-1-Factors Affecting the Preparation of Al-Si-Ni Ternary Alloy}

Preliminary experiments carried out to study the factors affecting the dissolution of silicon and nickel in the produced ternary Al-Si-Ni alloy. These factors are bath temperature, stirring speed, sodium fluosilicate to aluminum ratio, $\mathrm{Ni}_{2} \mathrm{O}_{3} / \mathrm{Al}_{\text {total }}$, and reaction time.

\section{3-1-1 Effect of bath temperature}

The effect of bath temperature (T) on metal thermic reduction of $\mathrm{Na}_{2} \mathrm{SiF}_{6}$ as a source of $\mathrm{Si}$ and $\mathrm{Ni}_{2} \mathrm{O}_{3}$ as a source of $\mathrm{Ni}$ with aluminum to obtain a ternary alloy $\mathrm{Al}-\mathrm{Si}-\mathrm{Ni}$ was investigated in the range from 800 to $1000^{\circ} \mathrm{C}$ at a reaction time 25 min., stirring speed $400 \mathrm{rpm}$, $\mathrm{Na}_{2} \mathrm{SiF}_{6} / \mathrm{Al}_{\text {total }}$ wt. ratio $1, \mathrm{Ni}_{2} \mathrm{O}_{3} / \mathrm{Al}_{\text {total }}$ wt. ratio 0.082 . As shown in Figure 1 , a linearly increasing noticed in silicon and nickel contents in the produced alloys, in range from 800 to $1000{ }^{\circ} \mathrm{C}$, the silicon percentage reached highest values at 950 and $1000{ }^{\circ} \mathrm{C}$. Moreover, a linear increasing of $\mathrm{Ni}$ is almost the same rate according to reaction (3), until the $\mathrm{Ni}$ contents in the produced ternary alloy $\mathrm{Al}-\mathrm{Si}-\mathrm{Ni}$ reached to the high value at $950{ }^{\circ} \mathrm{C}$.

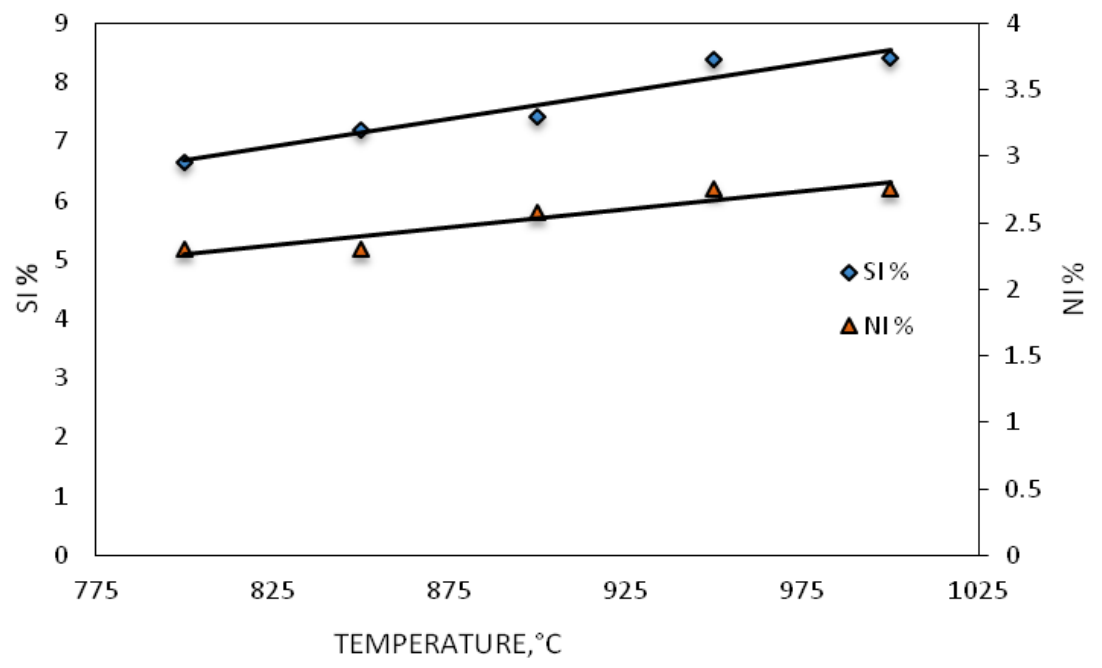

Figure 1 Effect of temperature on the $\mathrm{Si} \%$ and $\mathrm{Ni} \%$ of the prepared $\mathrm{Al}-\mathrm{Si}-\mathrm{Ni}$ ternary alloys

The increasing of $\mathrm{Si}$ and $\mathrm{Ni}$ contents of the alloy, as temperature rises, due to the formation of $\mathrm{AlF}_{3}$ and $\mathrm{NaF}$ in the reaction bath due to increasing of fluidity of bath and reduction of $\mathrm{SiF}_{4}$ and $\mathrm{Ni}_{2} \mathrm{O}_{3}$ with $\mathrm{Al}$ according to reaction (2) and (3). These results are in agreement with that obtained in literature [15]:

$$
\begin{aligned}
& \mathrm{Na}_{2} \mathrm{SiF}_{6} \\
& \mathrm{SiF}_{4} \text { (gas) } \\
& \Delta \mathrm{H}=+35.08 \mathrm{KCal} / \mathrm{mole} \\
& 3 \mathrm{SiF}_{4}+4 \mathrm{Al} \\
& \text { Si (im the alloy) }+4 \mathrm{AlF}_{3} \\
& \Delta \mathrm{H}=-286.06 \mathrm{KCal} / \text { mole } \\
& \mathrm{Ni}_{2} \mathrm{O}_{3}+2 \mathrm{Al} \\
& \text { 2Nith the alloy) }+\mathrm{Al}_{2} \mathrm{O}_{3} \\
& \Delta \mathrm{H}=-283 \mathrm{KCal} / \mathrm{mole}
\end{aligned}
$$

Figure $2 \mathrm{a}, \mathrm{b}$ and $\mathrm{c}$ represents the DTA for $\mathrm{Al}+\mathrm{Ni}_{2} \mathrm{O}_{3}, \mathrm{Al}+\mathrm{Na}_{2} \mathrm{SiF}_{6}, \mathrm{Al}+\mathrm{Na}_{2} \mathrm{SiF}_{6}+\mathrm{Ni}_{2} \mathrm{O}_{3}$ mixtures respectively. From Figure 2, it could be seen that, an endothermic peak at $568{ }^{\circ} \mathrm{C}$ is repeated in Figure $2 \mathrm{~b}$, c that represents the decomposition of $\mathrm{Na}_{2} \mathrm{SiF}_{6}$ to obtain sodium fluoride $\mathrm{NaF}$ and silicon tetra fluoride $\mathrm{SiF}_{4}$ which adsorbed on the surface of aluminum 
powder according to reaction (1) [15], while the endothermic peak at 658 is the latent heat of fusion for aluminum, because it repeats in Figure $2 \mathrm{a}, \mathrm{b}$ and c. There are two exothermic peaks; one of them at $821{ }^{\circ} \mathrm{C}$ Figure 2 a, c may be for the reaction of $\mathrm{Al}$ with $\mathrm{Ni}_{2} \mathrm{O}_{3}$ according reaction (3). The other exothermic peak, about $871^{\circ} \mathrm{C}$ Figure $2 \mathrm{~b}, \mathrm{c}$ possibly will be for $\mathrm{Al}$ and $\mathrm{Na}_{2} \mathrm{SiF}_{6}$ to obtain Al-Si alloy with $\mathrm{AlF}_{3}$ according to reaction (2), the presence of $\mathrm{Ni}_{2} \mathrm{O}_{3}$ decreasing the decomposition temperature for $\mathrm{Na}_{2} \mathrm{SiF}_{6}$ from 568 to $555^{\circ} \mathrm{C}$ Figure $2 \mathrm{~b}$, c.

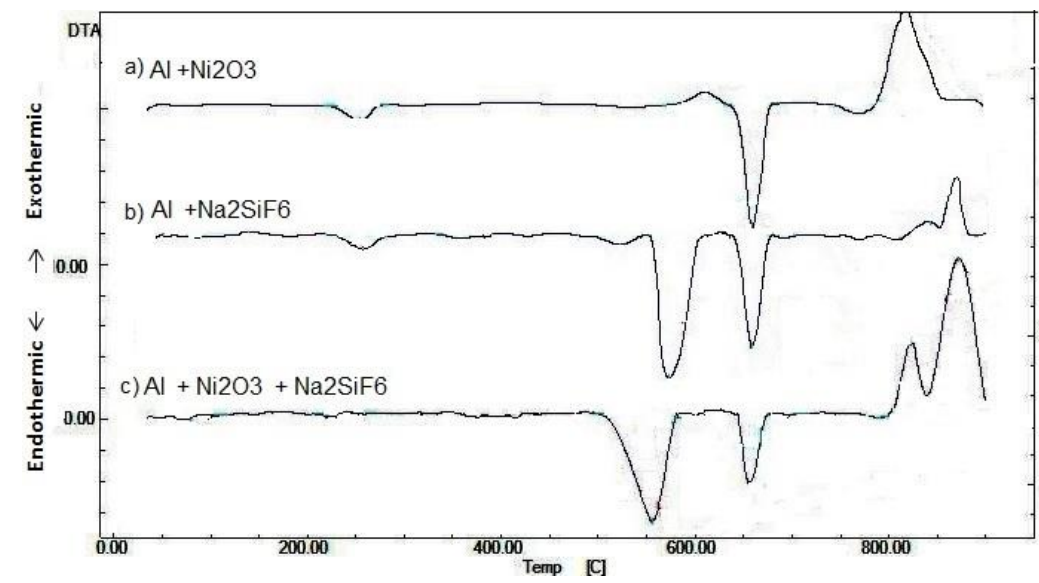

Figure 2 Differential thermal analysis (DTA) a) $\mathrm{Ni}_{2} \mathrm{O}_{3}+\mathrm{Al}$, b)Al-Na $\mathrm{NiF}_{6}$ and c)Al+Na $\mathrm{NiF}_{6}+\mathrm{Ni}_{2} \mathrm{O}_{3}$ mixtures

\section{3-1-2 Effect of Sodium fluosilicate ratio ( $F)$}

Experiments were conducted to study the effect of $\mathrm{Na}_{2} \mathrm{SiF}_{6} / \mathrm{Al}$ ratio (F) on the $\mathrm{Si}$ and $\mathrm{Ni}$ contents in the produced Al-Si-Ni ternary alloys. These experiments were carried out at various $\mathrm{Na}_{2} \mathrm{SiF}_{6} / \mathrm{Al}_{\text {total }}$ ratio from $(\mathrm{F} ; 0.25,0.5,0.75,1,1.25$, and 1.5 , where the other parameters kept constant at; reaction time $20 \mathrm{~min}$., stirring speed $400 \mathrm{rpm}$, temperature $950^{\circ} \mathrm{C}$, and $\mathrm{Ni}_{2} \mathrm{O}_{3} / \mathrm{Al}_{\text {total }}$ wt. ratio (N) 0.082. The obtained results demonstrated in Figure 3 . From this Figure, it could noticed that the silicon dissolution rate under the experimental conditions increases linearly as the $\mathrm{Na}_{2} \mathrm{SiF}_{6} / \mathrm{Al}_{\text {total }}$ wt. ratio $(\mathrm{F})$ raise its reaches to $10.75 \% \mathrm{Si}$ at a ratio equals to 1.5. The increasing of silicon dissolution could attribute to the increasing of silicon quantity in entering material that leads to produce more Si that dissolves in liquid aluminum as the reaction (2). On the other hand, the Ni contents increased sharply as the $\mathrm{Na}_{2} \mathrm{SiF}_{6} / \mathrm{Al}_{\text {total }}$ ratio increases to 0.75 but there is any remarkable changes in the range of 0.75 - $1.5 \mathrm{Na}_{2} \mathrm{SiF}_{6} / \mathrm{Al}_{\text {total }}$ wt. ratio. The increasing of $\mathrm{Ni}$ contents in the produced $\mathrm{Al}-\mathrm{Si}$-Ni ternary alloys in the range of $0-0.75$ attributed to increase of fluorine salts in the reaction bath that leads to push reaction towards the direction of producing more $\mathrm{Ni}$ dissolves in liquid aluminum according to reaction (3).

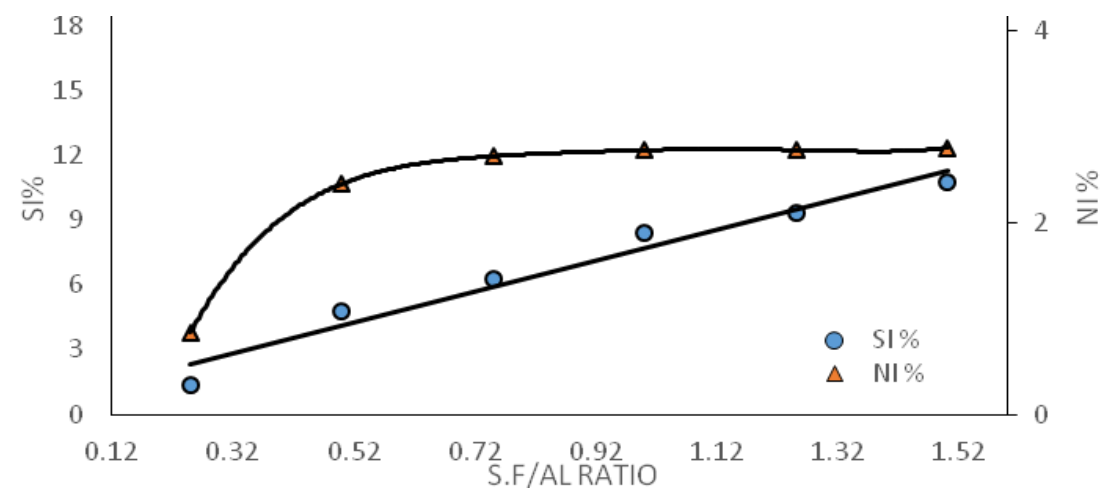

Figure 3 Effect of $\mathrm{Na} 2 \mathrm{SiF} 6 /$ Altotal wt. ratio on the $\mathrm{Si} \%$ and $\mathrm{Ni} \%$ of the prepared Al-Si-Ni ternary alloys. 


\section{3-1-3. Effect of nickel oxide ratio $(\mathrm{N})$}

The experiments were conducted to study the effect of $\mathrm{Ni}_{2} \mathrm{O}_{3} / \mathrm{Al}_{\text {total }}$ wt. ratio $(\mathrm{N})$ on the $\mathrm{Si}$ and $\mathrm{Ni}$ contents in the produced $\mathrm{Al}-\mathrm{Si}-\mathrm{Ni}$ ternary alloys. These experiments were carried out at various $\mathrm{Ni}_{2} \mathrm{O}_{3} / \mathrm{Al}_{\text {total }} \mathrm{Wt}$. ratio from( $\mathrm{N} ; 0.055$ to 0.12 where the other parameters kept constant at; reaction time $20 \mathrm{~min}$., stirring speed $400 \mathrm{rpm}$, Temperature $950^{\circ} \mathrm{C}$, and $\mathrm{Na}_{2} \mathrm{SiF}_{6} / \mathrm{Al}_{\text {total }}$ ratio $(\mathrm{F}) 1$ as shown in Figure 4. From this Figure, it could be illustrated that the silicon dissolution rate under the experimental conditions is almost constant as the nickel oxide ratio $(\mathrm{N})$ increases, it reaches to $8.4 \% \mathrm{Si}$ at a $\mathrm{N}$ equals to 0.082 . Then the $\mathrm{Si} \%$ in the produced alloys decreased as the nickel oxide ratio $\mathrm{N}$ increased. It could be attributed to the increasing of Nickel quantity in the added material that leads to produce more slag in the bath hindering the reaction (2) in turns decrease the $\mathrm{Si}$ that dissolves in liquid aluminum. On the other hand, the $\mathrm{Ni}$ contents increased sharply as the $\mathrm{Ni}_{2} \mathrm{O}_{3} / \mathrm{Al}_{\text {total }}$ wt. ratio $(\mathrm{N})$ increases. The increasing of $\mathrm{Ni}$ contents in the produced $\mathrm{Al}-\mathrm{Si}$-Ni ternary alloys in the range of $0-0.12$ attributed to increasing in the quantity of $\mathrm{Ni}_{2} \mathrm{O}_{3}$ in added material leads to producing more $\mathrm{Ni}$ that dissolves in liquid aluminum according to reaction (3).

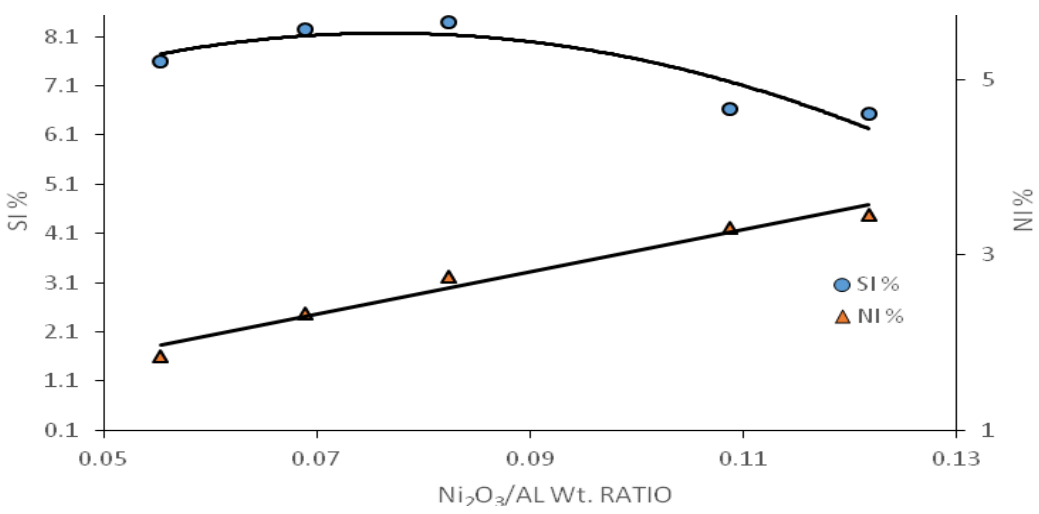

Figure 4 Effect of $\mathrm{Ni}_{2} \mathrm{O}_{3} / \mathrm{Al}_{\text {total }}$ wt. ratio on the $\mathrm{Si} \%$ and $\mathrm{Ni} \%$ of the prepared $\mathrm{Al}-\mathrm{Si}$-Ni ternary alloys

\section{3-1-5. Effect of reaction time $(t)$}

The effect of time were studied on the Si and Ni contents in the produced Al-Si-Ni ternary alloys from 5 to $30 \mathrm{~min}$. where the other parameters kept constant at; $\mathrm{Ni}_{2} \mathrm{O}_{3} / \mathrm{Al}_{\text {total }}$ wt. ratio 0.082 , stirring speed $400 \mathrm{rpm}$, temperature $950^{\circ} \mathrm{C}$, and $\mathrm{Na}_{2} \mathrm{SiF}_{6} / \mathrm{Al}_{\text {total }}$ ratio $(\mathrm{F}) 1$ as shown in Figure 5. It could be shown that the $\mathrm{Si} \%$ is slightly increases in the produced alloys as to more reaction time, but the $\mathrm{Ni}$ contents remained constant. It could be attributed to the vigorous reactions, for both reactions (2) and (3) at a time from 0 to 5 min specially. Reaction (3) leads to most of silicon and all nickel are transfer to the Al-Si-Ni ternary alloy in the first $5 \mathrm{~min}$. at more time the remaining Si transfer from the bath to the produced alloy in the range of 5 to 30 $\min$.

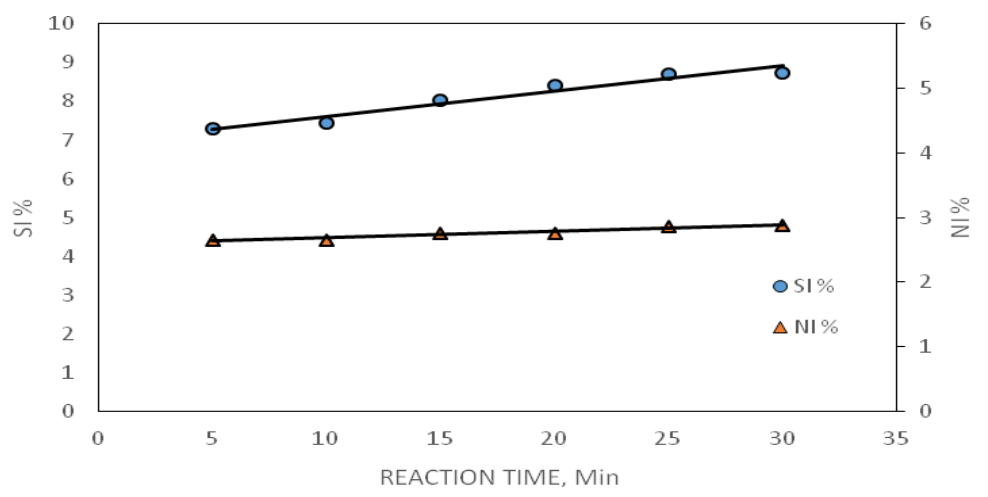

Figure 5 Effect of reaction time on the $\mathrm{Si} \%$ and $\mathrm{Ni} \%$ of the prepared Al-Si-Ni ternary alloys 


\section{3-2. Characterization of the Produced Alloys Al-Si-Ni Ternary Alloy}

The produced Al-Si-Ni ternary alloy in solid cylinder shape was analyzed using XRD with cupper tube.

The XRD patern for Al-Si-Ni ternary alloy containing 8.4 Si and 2.75 Ni indicated in Figure 6. It illustraed that, there are three phases was founded $\mathrm{Al}$ phase, aluminium silicon alloy $\mathrm{Al}_{3.21} \mathrm{Si}_{0.47}$ and $\mathrm{Al}_{3} \mathrm{Ni}$ intermetallic compound. The aluminium silicon alloy $\mathrm{Al}_{3.21} \mathrm{Si}_{0.47}$ contains about 87.3 at.\% $\mathrm{Al}$ and 12.7 at.\%Si. represent the eutectic composition.

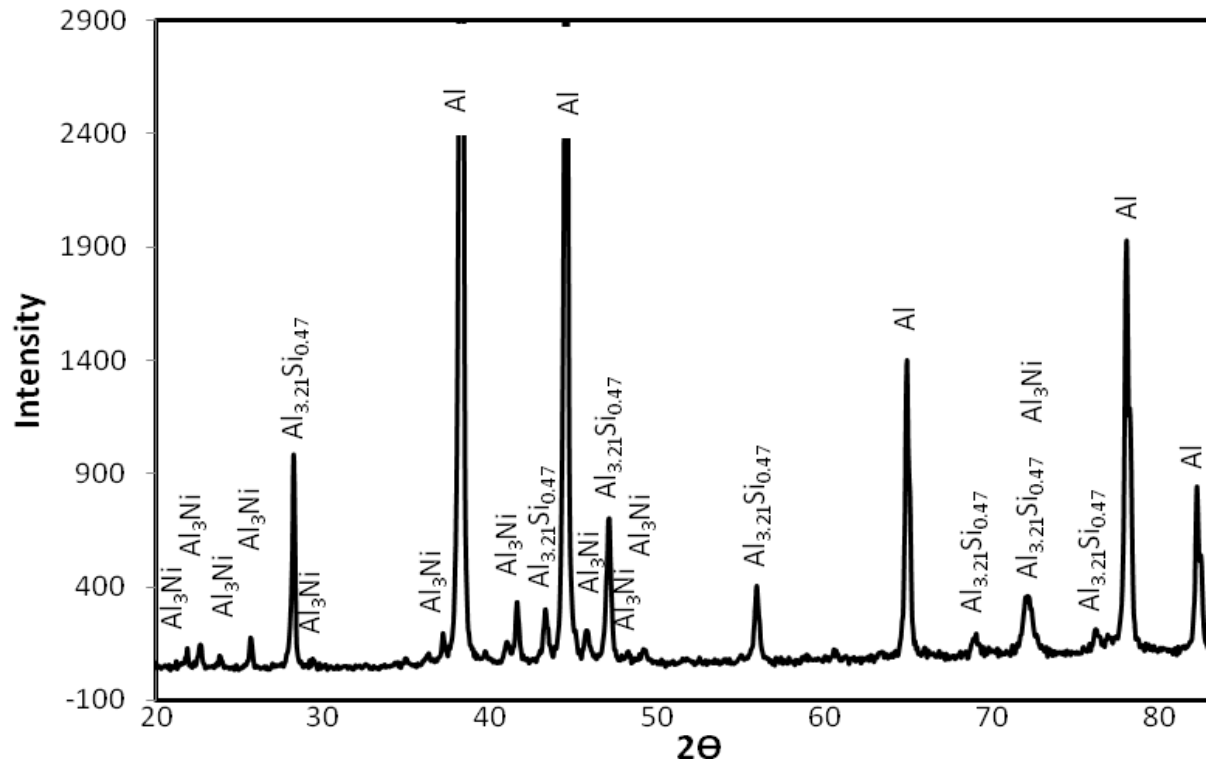

Figure 6 XRD diffraction for the produced Al-Si-Ni ternary alloy containing $8.4 \mathrm{Si}$ and $2.75 \mathrm{Ni}$.

The $\mathrm{Al}_{3} \mathrm{Ni}$ intermetallic compound from the Al-Ni binary phase diagram Figure7 formed at about $854^{\circ} \mathrm{C}$ and contained 25 at.\% Nickel and 75 at.\% aluminum. The $\mathrm{Al}_{3} \mathrm{Ni}$ intermetallic compound form eutectic with $\mathrm{Al}$ at about 4 at.\% $\mathrm{Ni}$ and $639.9{ }^{\circ} \mathrm{C}$ [16]. Moreover, the $\mathrm{Si}$ is soluble in $\mathrm{Al}$ at extent of 1.65 at.\% Si, it forms eutectic at 12.6 at.\% $\mathrm{Si}$ and eutectic temperature about $577{ }^{\circ} \mathrm{C}$ [16]. From the previous results, it could be observed that the produced alloys prepared at temperature more than $900^{\circ} \mathrm{C}$, this temperature is enough to form $\mathrm{Al}_{3} \mathrm{Ni}$ and $\mathrm{Al}-\mathrm{Si}$ alloy in the presence of molten $\mathrm{Al}, \mathrm{Si}$ and free $\mathrm{Ni}$ reduced from nickel oxide.

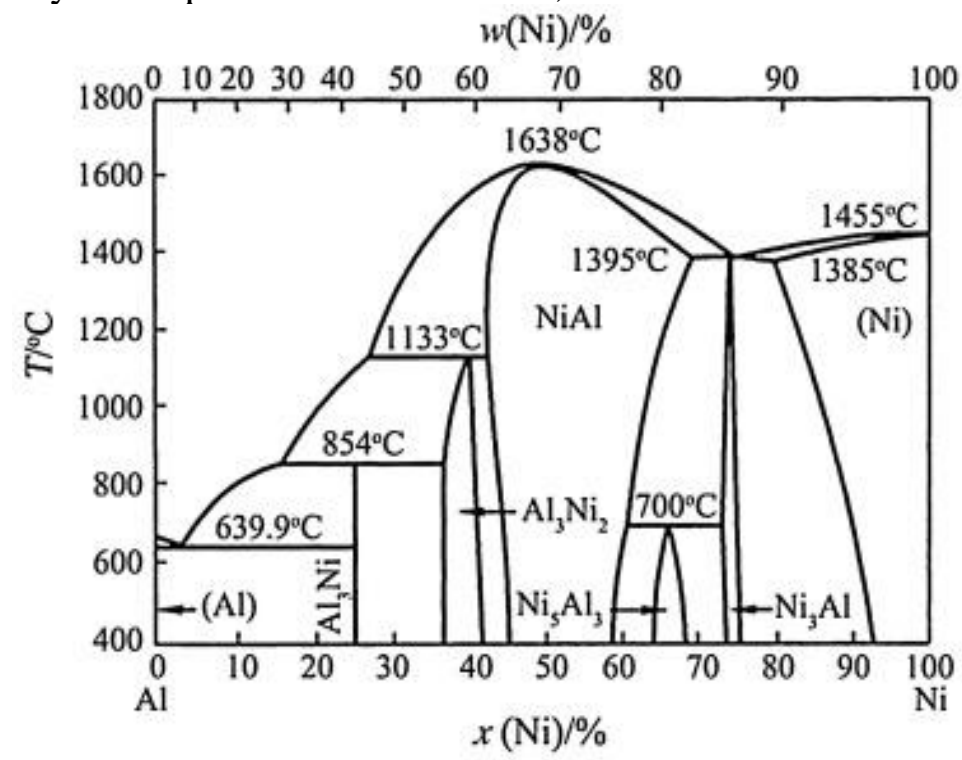

Figure 7 Al-Ni binary phase diagram [16] 
Figure 8 shows (a) light optical microscopy (LOM) and (b) scanning electron microscope (SEM) images of hypoeutectic Al-Si-Ni ternary alloy containing 8.4Si and 2,75 Ni. From the polarized reflected light microscope (LOM) as shown in Figure 8a it could be shown that, three phases are presented. Light phase (kidney shape), brownish phase (needle shape), and dark gray color (small particles), the light phase is surrounded by the brownish phase and the dark gray phase, but the brownish phase lied on the grain boundary of the light phase and interconnected with the dark gray phase. The SEM image Figure 8b mapping for the same specimen containing $8.4 \mathrm{Si}$ and $2,75 \mathrm{Ni}$, it could be noticed that three colors appear in the matrix; dark blue represent the $\mathrm{Al}$ phase, the light blue color is $\mathrm{Si}$ and the light red color is the Ni. According to comparison between Fig.8a and Fig.8b, it seems to be at the same structure. The light phase in Figure 8 is the same shape of the $\alpha \mathrm{Al}$ phase (dark blue) in Figure $8 \mathrm{~b}$. The brownish phase in Figure 8a is matching to the Ni phase (light red color) in Figure 8b, this result confirmed with the results of XRD Figure 6. The dark gray phases in Figure 8a represent the $\mathrm{Si}$ phase as shown in Figure $8 \mathrm{~b}$ (light blue color). Also from Figure $8 \mathrm{~b}$, the $\mathrm{Si}$ phase (light blue) is mixed mechanically with $\mathrm{Al}$ (dark blue color) represents the fine eutectic Si.

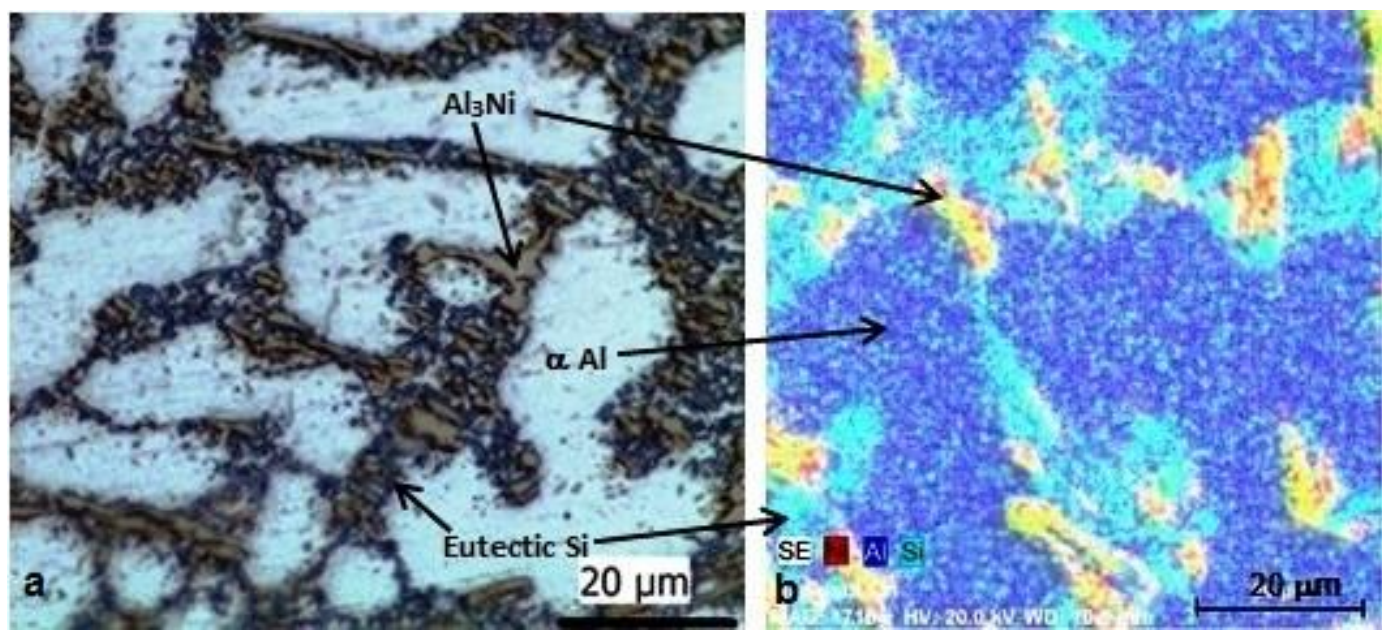

Figure 8 (a) LOM and (b) SEM images of hypoeutectic Al-Si-Ni alloy containing 8.4 Si and 2.75 Ni, etched by $0.5 \%$ HF acid.

Figure 9 a, b shows Energy Dispersive X-ray (EDX) mapping of the same alloy in Figure 8 containing $8.4 \mathrm{Si}$ and $2,75 \mathrm{Ni}$, it could be shown that three phases are presented in the main photo; Light gray phase surrounded by another fine light gray phase contain a White needle like phase Figure 9 a. The EDX mapping for Ni, Al, and Si elements are illustrated in Figure $9 \mathrm{~b}$, c and d respectively. Figure $9 \mathrm{~b}$ shows the needle like phase (red color) within black matrix is $\mathrm{Al}_{3} \mathrm{Ni}$ intermetallic compound. Also, Figure $9 \mathrm{c}$ demonstrates the blue color (kidney shape) is $\alpha$ aluminum surrounded by blue particles (eutectic Al) within black areas. Moreover, Figure 9 d shows small blue-green interconnected particles (eutectic Si). The mechanism of Al-Si-Ni ternary alloy of solidification as follows, the $\alpha \mathrm{Al}$ is solidified first in the mold followed by the eutectic $\mathrm{Al}_{3} \mathrm{Ni}$ which is precipitated at the grain boundary of $\alpha \mathrm{Al}$ and last precipitate eutectic $\mathrm{Al}-\mathrm{Si}$ interconnected with $\mathrm{Al}_{3} \mathrm{Ni}$ making geometrical entangled system[8]. The results was conformed with the results of XRD Figure 6 [8]. 

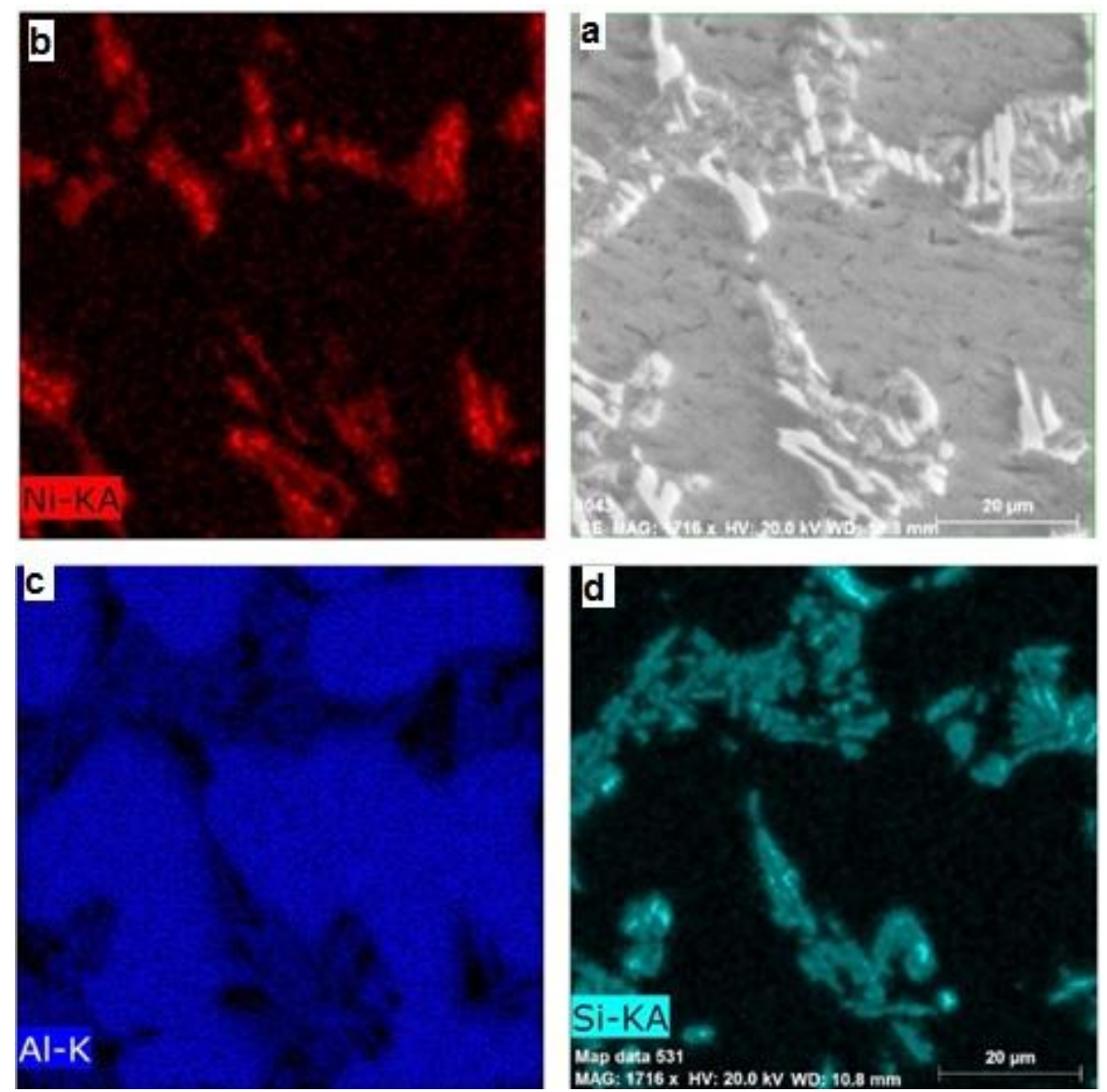

Figure 9 EDX mapping of hypoeutectic Al-Si-Ni ternary alloy containing 8.4 Si and 2.75 Ni.

\section{CONCLUSIONS}

The experiments were conducted to study the parameters affecting the fabrication of AlSi-Ni ternary alloys. The results could conclude as follows:

1. The produced Al-Si-Ni ternary alloys containing up to $10.75 \% \mathrm{Si}$ and $2.86 \mathrm{Ni}$ in the form of $\mathrm{Al}_{3} \mathrm{Ni}$.

2. The optimum processing parameters are temperature $950^{\circ} \mathrm{C}, \mathrm{Na}_{2} \mathrm{SiF}_{6} / \mathrm{Al}_{\text {total }}$ w.t ratio is $1, \mathrm{Ni}_{2} \mathrm{O}_{3} / \mathrm{Al}_{\text {total }}$ wt. ratio is 0.082 and reaction time is $25 \mathrm{~min}$.

3. The results of $\mathrm{X}$-ray diffraction proved that the Nickel form $\mathrm{Al}_{3} \mathrm{Ni}$ intermetallic compound.

4. The microstructure examination illustrated that the $\mathrm{Al}_{3} \mathrm{Ni}$ in the form of needle like and interconnected and entangled with eutectic Si leads to reinforcement the $\alpha \mathrm{Al}$ matrix and may be enhanced mechanical property.

5. The presence of eutectic $\mathrm{Si}$ and eutectic $\mathrm{Al}_{3} \mathrm{Ni}$ form entangled system and it could be used as high performance alloys at elevated temperature.

\section{REFERENCES}

[1] J.E. Gruzleski, B.M. Closset, "The treatment of liquid aluminum-ailicon alloys", American Foundrymen's society, 1999, pp 1-256.

[2] Ebrahiem, E.,E., Ibrahim, H.,A., Noval, A.,A., and Omran, A.,M., "Dissolution kinetics of silicon- containing sodium fluosilicate in stirred bath of molten aluminum", Light Metal, $131^{\text {st }}$ TMS, Annual Meeting Seattle, Washington 2002, pp 17-21

[3] Florin Stadler, Helmut Antrekowitsch, Werner Fragner, Helmut Kaufmann and Peter J. Uggowitzer "The Effect of Ni on the high-temperature strength of Al-Si cast alloys", Materials Science Forum, Vol. 690, 2011, pp. 274-277. 
[4] I. J. Polmear: 'Light alloys: from traditional alloys to nanocrystals'; 2004, London, Butterworth \& Co.

[5] F. Hernández-Méndez1, A. Altamirano-Torres , José Miranda-Hernández, E. TérresRojas, and E. Rocha-Rangel, "Effect of Nickel Addition on Microstructure and Mechanical Properties of Aluminum-Based Alloys" International Journal of Scientific and Research Publications,. Vol. 691, 2012 pp. 10-14

[6] M. El kemary, N. Nagy, I. El Mehasseb 'Nickel oxide nanoparticles synthesis and spectral studies of interaction with glucose" material science in semiconductor processing, Vol. 16, 2013, pp. 1747-1752

[7] Tundermann JH, Tien JK, Howson TE (2005). Nickel and nickel alloys. In: Kirk-Othmer Encyclopedia of Chemical Technology. Vol. 17. (Online edition)

[8] Stadler, H. Antrekowitsch, W. Fragner, H. Kaufmann and P. J. Uggowitzer "Effect of alloying elements on elevated temperature strength of Al-Si alloys" International Journal of Cast Metals Research, Vol. 25, 2012, pp. 215-224

[9] L. Sang-Yong, L. Jung-Hwan, and L. Young-Seon, "Characterization of Al 7075 alloys after cold working and heating in the semi-solid temperature range", Journal of Materials Processing Technology, Vol. 111, 2001, pp. 42-47.

[10] D. Srinivasan and K. Chattopadahyay, "Metastable phase evolution and hardness of nanocrystalline Al Si-Zr alloys", Materials Science and Engineering A, Vols. 304-306, 2001, pp. $534-539$.

[11] P. Seperband, R. Mahmudi, and F. Khomamizadeh, "Effect of Zr addition on the aging behavior of A319 aluminum cast alloy", Scripta Materialia, Vol. 52, 2005, pp. 253-257.

[12] Z. Asghar, G. Requena, and F. Kubel, "The role of Ni and Fe aluminides on the elevated temperature strength of an AlSi12 alloy", Materials Science and Engineering A, Vol. A527, 2010, pp. 91- 98.

[13] S. Mudryi, I. Shtablavyii, "Cluster structure in Al-Si eutectic melt with solid Ni particles",Chem. Met. Alloys Vol. 1, 2008, pp. 163-167

[14] Rakhmonov, J., G. Timelli, and F. Bonollo, "The Effect of Transition Elements on HighTemperature Mechanical Properties of Al-Si Foundry Alloys-A Review", Advanced Engineering Materials, 2016, Vol. 18(7), pp. 1096-1105

[15] A. M. Omran, "Study the parameters affecting the production of Al-Si alloys from sodium fluosilicate", M. Sc., Chem. Eng. Dept., Faculty of Engineering, El-Minia University, 1998.

[16]. P. Nash, M.F. Singleton, and J.L. Murray, ASM Handbook, Vol. 3: Alloy-Phase Diagrams, 10th Edition, ASM, Materials Park, Ohio (1992). 